\title{
IMPLEMENTASI SUPERVISI KLINIS DALAM MENINGKATKAN KEMAMPUAN MENGAJAR GURU MATA PELAJARAN AKIDAH AKHLAK
}

\author{
Slamet Riyadi \\ Madrasah Aliyah Negeri, Rejotangan Kabupaten Tulungagung \\ email: man_ta_1@yahoo.co.id
}

\begin{abstract}
Implementation of Clinical Supervision in improving the Ability of Teachers to Teach the Subjects Moral Creed. Clinical supervision is one of the efforts in improving the professionalism of teachers. This research aims to (1) find out the implementation of clinical supervision in improving the ability of teaching; and (2) determine whether clinical supervision techniques can increase the ability of teachers to teach the subjects Moral Creed on MAN Rejotangan Tulungagung. This research uses qualitative descriptive method with the class action research design. The results showed that the implementation of clinical supervision is going well and can increase the capability of the teachers teaching in the subjects Moral Creed.
\end{abstract}

Keywords: clinical supervision implementation, ability to teach teachers

\begin{abstract}
Abstrak: Implementasi Supervisi Klinis dalam Meningkatkan Kemampuan Mengajar Guru Mata Pelajaran Akidah Akhlak. Supervisi klinis merupakan salah satu upaya dalam meningkatkan profesionalisme guru. Penelitian ini bertujuan untuk (1) mengetahui implementasi supervisi klinis dalam meningkatkan kemampuan mengajar; dan (2) mengetahui apakah teknik supervisi klinis dapat meningkatkan kemampuan mengajar guru mata pelajaran Akidah Akhlak di MAN Rejotangan Tulungagung. Penelitian ini menggunakan metode deskriptif kualitatif dengan rancangan penelitian tindakan kelas. Hasil penelitian menunjukkan bahwa pelaksanaan supervisi klinis berjalan dengan baik dan dapat meningkatkan kemampuan mengajar guru pada mata pelajaran Akidah Akhlak.
\end{abstract}

Kata Kunci: implementasi supervisi klinis, kemampuan mengajar guru

Peraturan Menteri Pendidikan Nasional (Permendiknas) Nomor 41 Tahun 2007 merupakan salah satu acuan utama bagi satuan pendidikan dalam proses penyelenggaraan pembelajaran mulai dari perencanaan proses pembelajaran, pelaksanaan pembelajaran, penilaian hasil pembelajaran dan pengawasan proses pembelajaran. Permendiknas Nomor 41 ini dimaksudkan dapat meningkatkan mutu lulusan dalam mencapai standar kompetensi lulusan yang pada akhirnya dapat menjadikan mutu pendidikan semakin baik. Oleh karena itu, proses pembelajaran harus benar-benar dipersiapkan dengan baik, antara lain melalui penyiapan penyusunan Rencana Pelaksanaan Pembelajaran
(RPP) dan pelaksanaan proses pembelajaran yang dilaksanakan secara fleksibel dengan memanfaatkan seluruh sumber daya yang tersedia baik di dalam sekolah maupun di luar sekolah.

Miarso (1985) mengatakan bahwa, salah satu faktor utama yang sangat menentukan dalam meningkatkan mutu pendidikan adalah guru. Guru merupakan titik sentral dalam pembaharuan dan peningkatan mutu pendidikan, dan salah satu upaya peningkatan kemampuan profesional guru adalah melalui supervisi klinis (Bafadal, 2006). Kegiatan proses pembelajaran merupakan hal yang pokok dalam mencapai kompetensi yang harus dikuasai oleh masing-masing siswa, bila para guru 
memiliki kemampuan mengajar yang baik maka proses pembelajaran akan berjalan dengan efektif dan efisien.

Bila ditelaah dari akar kata, supervisi berasal dari bahasa Inggris "supervision" yang terdiri dari dua kata yaitu "super" dan "vision". Super berarti atas atau lebih, sedangkan vision berarti melihat atau meninjau (Nawawi, 1984). Bila ditinjau dari segi makna (semantik) ada beberapa pandangan tentang pengertian supervisi. Menurut Wiles (dalam Sutisna, 1983) mengemukakan bahwa supervisi adalah bantuan yang diberikan untuk memperbaiki situasi belajar mengajar yang lebih. Adam \& Dickey (dalam Sahertian, 2000) mendefinisikan supervisi adalah program yang terencana untuk memperbaiki pengajaran. Boardman (dalam Sahertian, 2000) mendefinisikan bahwa supervisi adalah suatu usaha menstimulasi, mengkoordinasi dan membimbing secara berkelanjutan pertumbuhan guru-guru di sekolah, baik secara individual maupun secara kolektif, agar lebih mengerti dan lebih efektif dalam mewujudkan seluruh fungsi pengajaran. McNerney (dalam Sahertian, 2000) melihat supervisi itu sebagai suatu prosedur yang memberi arah serta mengadakan penilaian secara kritis terhadap proses pengajaran.

Berdasarkan beberapa pendapat tersebut, maka dapat disimpulkan ada beberapa prinsip dasar dalam supervisi. Pertama, supervisi merupakan suatu proses usaha, karena dalam supervisi terdapat langkah-langkah kegiatan yang dilakukan oleh supervisor. Kedua, supervisi merupakan bantuan ke arah perbaikan proses pembelajaran, bantuan tersebut dalam rangka meningkatkan kemampuan guru dalam mengelola proses pembelajaran, sehingga diharapkan proses pembelajaran dapat berjalan efektif dan efisien. Ketiga, supervisi adalah meningkatkan kemampuan guru dalam proses pembelajaran. Adanya supervisi, guru semakin mampu dalam mengelola proses pembelajaran sehingga situasi pembelajaran nampak kondusif, anak semakin aktif, dan semua kompetensi yang ditargetkan akan tercapai, baik dari segi pengetahuan, keterampilan dan sikap. Tujuan supervisi ialah memberikan bantuan kepada guru-guru untuk meningkatkan kualitas mengajar guru, yang pada gilirannya dapat meningkatkan kualitas belajar siswa. Pendapat ini sesuai dengan apa yang dikemukakan oleh Olive (dalam Sahertian, 2000) bahwa sasaran supervisi pendidikan ialah mengembangkan kurikulum yang sedang dilaksanakan di sekolah, meningkatkan proses belajar mengajar di sekolah, mengembangkam seluruh staf di sekolah.

Supervisi klinis adalah bentuk supervisi yang difokuskan pada peningkatan mengajar melalui siklus yang sistematis dalam perencanaan, pengamatan serta analisis yang intensif dan cermat tentang penampilan mengajar yang nyata serta bertujuan mengadakan perubahan dengan cara yang rasional (Willem dalam Sahertian, 2000). Menurut Cogan (dalam Bafadal, 2006) supervisi klinis merupakan pembinaan kinerja guru dalam mengelola proses belajar mengajar. Menurut Weller (dalam Nurtain, 1989) bentuk supervisi yang difokuskan pada peningkatan mengajar melalui sarana siklus yang sistematis dalam perencanaan, pengamatan serta analisis yang intelektual dan intensif mengenai penampilan mengajar yang nyata dalam mengadakan perubahan secara rasional. Menurut Acheson \& Gall (dalam Purwanto, 1987) supervisi klinis adalah proses membantu guru memperkecil kesenjangan antara tingkah laku mengajar yang nyata dengan tingkah laku mengajar yang ideal. Menurut Bolla (dalam Purwanto, 1987) supervisi klinis adalah suatu proses bimbingan yang bertujuan untuk membantu pengembangan profesional guru/calon guru, khususnya dalam penampilan mengajar, berdasarkan observasi dan analisis data secara teliti dan obyektif sebagai pegangan untuk perubahan tingkah laku mengajar tersebut. Dengan demikian dapat disimpulkan bahwa supervisi klinis adalah bantuan yang diberikan oleh supervisor untuk meningkatkan kemampuan mengajar melalui siklus yang sistematis sehingga terjadi proses pembelajaran yang efektif dan efisien.

Berdasarkan uraian di atas, tergambar bahwa penelitian ini bertujuan untuk mengetahui bagaimana implementasi supervisi klinis dalam meningkatkan kemampuan mengajar guru dan apakah teknik supervisi klinis tersebut dapat meningkatkan kemampuan mengajar guru mata pelajaran Akidah Akhlak di Madrasah Aliyah Negeri (MAN) Rejotangan Kabupaten Tulungagung. 


\section{METODE}

Penelitian ini menggunakan metode penelitian deskriptif kualitatif. Penelitian kualitatif yang digunakan dalam penelitian ini bermaksud mengetahui dan mendeskripsikan tentang kemampuan mengajar guru dan pelaksanaan teknik supervisi klinis di MAN Rejotangan Kabupaten Tulungagung. Penelitian ini menggunakan rancangan penelitian tindakan kelas McNiff (1988) dan Kemmis \& Taggart (1988) menyebutkan bahwa satu rangkaian perencanaan, tindakan, observasi dan refleksi disebut sebagai siklus dan refleksi pada siklus I akan menentukan apakah siklus I itu dicukupkan atau diteruskan ke siklus kedua dan seterusnya. Dengan demikian dalam penelitian ini menggunakan rancangan yang meliputi perencanaan tindakan, pelaksanaan tindakan, observasi dan refleksi.

Terdapat dua variabel dalam penelitian. Variabel pertama adalah variabel kemampuan mengajar guru (Y), yang dijabarkan sebagai berikut (1) Prapembelajaran; (2) Kegiatan inti pembelajaran; dan (3) Kegiatan penutup. Variabel kedua adalah variabel pelaksanaan supervisi klinis (X), yang dijabarkan sebagai berikut (1) Tahap pertemuan awal; (2) Tahap observasi mengajar; dan (3) Tahap pertemuan balikan. Penelitian ini berlokasi di MAN Rejotangan Kabupaten Tulungagung. Subyek dalam penelitian ini adalah peneliti sendiri sebab peneliti bertindak sebagai kepala sekolah di MAN Rejotangan Tulungagung. Objek dalam penelitian ini adalah guru mata pelajaran akidah akhlak MAN Rejotangan Tulungagung.

Prosedur dalam penelitian ini berawal dari perencanaan. Ada beberapa hal yang perlu direncanakan (1) Pertemuan awal antara kepala sekolah (supervisor) dengan guru mata pelajaran akidah akhlak; (2) Menentukan materi pertemuan awal (3) Pengamatan proses pembelajaran dan menentukan alat ukur yang digunakan untuk mengukur kesempurnaan RPP dan keberhasilan dalam proses pembelajaran; dan (4) Pertemuan balikan dan materi pertemuan balikan. Kemudian dalam tahap pelaksanaan tindakan, guru melaksanakan proses pembelajaran sesuai dengan instrumen yang telah disusun. Selanjutnya adalah tahap observasi yang dilakukan pada saat guru melaksanakan pembelajaran serta mencatat dan memberi skor pada instrumen RPP dan instrumen pelaksanaan pembelajaran. Hasil pengamatan ini selanjutnya dievaluasi bersama sehingga dapat dijadikan acuan untuk melaksanakan analisa pada tahap refleksi.

\section{HASIL DAN PEMBAHASAN}

\section{Hasil}

\section{Siklus I}

Pada siklus I, hasil RPP yang telah direvisi diberikan skor berdasarkan pedoman penilaian RPP, yaitu 25. Pada tahap perencanaan terdapat beberapa temuan dalam penyusunan RPP yang belum sempurna sehingga perlu revisi antara lain relevansi antara penyusunan materi ajar dengan tujuan pembelajaran, pengorganisasian materi ajar yang kurang baik dilihat dari sistematika materi ajar, langkah-langkah kegiatan pembelajaran perlu tambahan beberapa strategi pembelajaran, misalnya pemodelan, inquiry, learning community, performance dan sebagainya, sumber pembelajaran yang tidak jelas dan bentuk penilaian yang tidak lengkap.

Selama proses pelaksanaan pembelajaran, hasil yang diperoleh guru Akidah Akhlak adalah 81. Terdapat beberapa hal yang masih belum sesuai dengan pedoman pelaksanaan pembelajaran antara lain (1) Pada kegiatan prapembelajaran siswa tidak dipersiapkan dulu dan guru langsung menjelaskan materi ajar; (2) Pada kegiatan awal, guru belum bisa membedakan pengertian apersepsi dan pretest; (3) Guru belum bisa menjelaskan atau mengkondisikan situasi pembelajaran yang mengaitkan antara materi dengan pengetahuan lain yang relevan; (4) Guru belum bisa mengaitkan antara materi dengan praktek di lapangan/masyarakat; (5) Kelas belum bisa dikuasai; (6) Pembelajaran belum mengarah pada kontekstual; (7) Penggunaan media belum maksimal dan kurang menarik perhatian pada siswa; (8) Pemanfaatan media tidak melibatkan siswa; (9) Siswa bersifat pasif; (10) Suasana pembelajaran belum bisa menumbuhkan keceriaan dan antusiasme siswa dalam belajar; (11) Penilaian proses pembelajaran belum nampak; (12) Soal posttest belum sesuai dengan tujuan pembelajaran yang telah ditetapkan; (13) Kegiatan refleksi belum dilaksanakan; dan (14) Kegiatan remidi (pengayaan) belum dilaksanakan. 


\section{Siklus II}

Pada siklus II, ditemukan bahwa penyusunan RPP belum sempurna. Pada penyusunan RPP masih banyak hal-hal yang belum sesuai dengan pedoman penyusunan RPP sehingga guru perlu memperbaikinya kembali. Hasil RPP yang telah direvisi diberikan skor berdasarkan pedoman penilaian RPP, yaitu 38. Kemudian pada tahap pelaksanaan, guru mengacu pada peningkatan kemampuan mengajar yang ada pada tahap pertama guru memperoleh skor 81 yang sebenarnya sangat dimungkinkan untuk memperoleh skor yang lebih tinggi.

Pada tahap observasi, guru sudah bisa mengadakan inovasi yang mengarah pada siswa aktif, kondusif, kontekstual dengan menggunakan media yang sesuai dengan materi ajar. Guru telah dapat membangun suasana yang menumbuhkan partisipasi aktif dari siswa, mampu mengadakan penilaian proses maupun hasil sesuai dengan tujuan pembelajaran yang telah ditetapkan semula, serta menggunakan bahasa yang jelas dan menarik. Pada kegiatan penutup telah ada kegiatan refleksi serta tindak lanjut yaitu remidi maupun pengayaan. Pada tahap ini diberikan penilaian terhadap pelaksanaan proses pembelajaran. Adapun skor hasil penilaian pelaksanaan siklus kedua ini adalah 107 .

\section{Pembahasan}

Proses pembelajaran guru wajib menyelenggarakan pembelajaran mendidik yang meliputi (1) Memahami prinsip-prinsip perancangan pembelajaran yang mendidik; (2) Mengembangkan komponen-komponen rancangan pembelajaran; (3) Menyusun rancangan pembelajaran yang lengkap, baik untuk kegiatan di dalam kelas, laboratorium maupun lapangan; (3) Melaksanakan pembelajaran yang mendidik di kelas, di laboratorium dan di lapangan dengan memperhatikan standar keamanan yang dipersyaratkan; (4) Menggunakan media pembelajaran dan sumber belajar yang sesuai dengan karakteristik peserta didik dan mata pelajaran yang diampu untuk mencapai tujuan pembelajaran secara utuh; dan (5) Mengambil keputusan transaksional dalam pembelajaran yang diampu sesuai dengan situasi yang berkembang.

Menurut Hariwung (1989) tujuan super-visi adalah untuk pengendalian kualitas, pengem- bangan profesional, dan memotivasi guru. Sedangkan fungsi supervisi adalah memperbaiki situasi proses pembelajaran melalui peningkatan kemampuan mengajar guru. Hal ini sesuai dengan pendapat Wiles (dalam Sahertian, 2000) bahwa fungsi dasar supervisi ialah memperbaiki situasi belajar mengajar dalam arti yang luas. Menurut Swearingen (dalam Sahertian, 2000) ada 8 fungsi supervisi yaitu mengkoordinasi semua usaha sekolah, melengkapi kepemimpinan sekolah, memperluas pengalaman guru, menstimulasi usaha-usaha yang kreatif, memberi fasilitas dan penilaian yang terus menerus, menganalisis situasi belajar-mengajar, memberikan pengetahuan dan keterampilan kepada setiap anggota staf, memberi wawasan yang lebih luas dan terintegrasi dalam merumuskan tujuan-tujuan pendidikan dan meningkatkan kemampuan mengajar guru.

Berikut ciri-ciri supervisi klinis untuk dapat dibedakan dengan supervisi lain (1) Pembimbingan yang diberikan oleh supervisor kepada guru bersifat bantuan, bukan perintah atau instruksi; (2) Jenis keterampilan yang akan di supervisi oleh supervisor diusulkan oleh guru terlebih dahulu dengan diadakan kesepakatan melalui pengkajian bersama antara guru dan supervisor; (3) Instrumen observasi dikembangkan/disepakati bersama antara supervisor dan guru sesuai dengan kontrak yang disetujui kedua belah pihak; (4) Umpan balik kegiatan mengajar guru diberikan dengan segera dan obyektif; (5) Meskipun supervisor telah menganalisis dan menginterpretasikan data yang direkam dalam observasi, tapi dalam diskusi umpan balik, guru terlebih dulu diminta menganalisis penampilannya; (6) Supervisor lebih banyak mendengarkan dan bertanya dari pada memerintahkan atau mengarahkan; (7) Supervisi berlangsung dalam suasana intim dan bersifat terbuka antara supervisor dan guru; (8) Supervisi berlangsung dalam siklus yang meliputi perencanaan, observasi dan diskusi umpan balik; dan (9) Supervisi klinis dapat dipergunakan untuk pembentukan atau peningkatan dan perbaikan keterampilan mengajar.

Supervisi klinis juga memiliki prinsipprinsip yang meliputi (1) Supervisi klinis yang dilaksanakan harus berdasarkan inisiatif dari para guru lebih dahulu; (2) Ciptakan hubungan manusia yang bersifat interaktif dan rasa kesejawatan; (3) 
Ciptakan suasana bebas dimana setiap orang bebas mengemukakan apa yang dialaminya; (4) Obyek kajian adalah kebutuhan profesional guru yang dialami secara nyata; dan (5) Perhatian dipusatkan pada unsur-unsur spesifik yang harus diangkat untuk diperbaiki.

Menurut Cogan (dalam Bafadal, 2006) ada 8 kegiatan dalam supervisi klinis antara lain tahap membangun dan memantapkan hubungan guru dan supervisor, tahap perencanaan bersama guru, tahap perencanaan strategi observasi, tahap observasi pengajaran, tahap analisis proses belajar mengajar, tahap perencanaan strategi pertemuan, tahap pertemuan, dan tahap penjajakan rencana pertemuan berikutnya. Selain itu, Mosher \& Purpel (dalam Bafadal, 2006) mengungkapkan ada 3 aktivitas dalam proses supervisi klinis yaitu tahap perencanaan, tahap observasi dan tahap evaluasi, dan tahap analisis. Kemudian Olivia (dalam Bafadal, 2006) menyebutkan ada 3 aktivitas esensial dalam proses supervisi klinis yaitu kontak dan komunikasi dengan guru untuk merencanakan observasi kelas, observasi kelas dan tindak lanjut observasi kelas. Menurut Krajewski, dkk (dalam Bafadal, 2006) ada 5 kegiatan dalam proses supervisi klinis yang disebut sequence of supervision ialah pertemuan sebelum observasi, observasi, analisis dan strategi, pertemuan supervisi dan analisis sesudah pertemuan supervisi. Menurut Manca, dkk (dalam Bafadal, 2006) ada 3 tahap kegiatan supervisi klinis yaitu tahap pertemuan awal, tahap observasi mengajar dan tahap pertemuan balikan.

Hasil penelitian berupa penyusunan RPP pada siklus I mendapatkan skor 25. Dari hasil penilaian RPP tersebut kemudian disesuaikan dengan skala penilaian RPP yang telah dibuat sebagai berikut pada Tabel 1.

Berpijak pada skala tersebut maka RPP pada siklus I dengan skor 25 termasuk dalam katagori "baik". Kemudian pada siklus II RPP direvisi dan disempurnakan. Berdasarkan hasil penilaian, dokumen RPP pada siklus II memperoleh skor 38. Dengan demikian RPP pada siklus II termasuk dalam katagori "baik sekali".

Hasil penelitian yang berupa pelaksanaan proses pembelajaran pada siklus I diperoleh skor 81. Dari hasil penilaian pelaksanaan proses pembelajaran tersebut kemudian disesuaikan dengan skala penilaian pelaksanaan proses pembelajaran yang telah dibuat sebagai berikut pada Tabel 2.

Berpijak pada skala tersebut maka pelaksanaan pembelajaran siklus I dengan skor 81 termasuk dalam katagori "baik". Sedangkan pada siklus II pelaksanaan pembelajaran mendapatkan skor 107, sehingga pelaksanaan pembelajaran pada siklus II termasuk katagori "baik sekali".

Berdasarkan temuan-temuan tersebut maka dapat disimpulkan bahwa, teknik supervisi klinis dapat dilaksanakan oleh kepala sekolah atau supervisor dengan hasil yang efektif dan efisien. Selain itu, terbukti jika teknik supervisi klinis dilaksanakan maka dapat meningkatkan kemampuan mengajar guru, dengan bukti adanya perubahan hasil penilaian RPP pada siklus I dan II yang meningkat dari 81 menjadi 107.

\section{Tabel 1 Skala Penilaian RPP}

\begin{tabular}{cccccc}
\hline Skor & 1 & - & 10 & Kategori & Kurang \\
Skor & 11 & - & 20 & Kategori & Cukup \\
Skor & 21 & - & 30 & Kategori & Baik \\
Skor & 31 & - & 40 & Kategori & $\begin{array}{c}\text { Baik } \\
\text { Sekali }\end{array}$ \\
\hline
\end{tabular}

Tabel 2 Skala Penilaian Pelaksanaan Proses Pembelajaran

\begin{tabular}{cccccc}
\hline Skor & 1 & - & 30 & Kategori & Kurang \\
Skor & 31 & - & 60 & Kategori & Cukup \\
Skor & 61 & - & 90 & Kategori & Baik \\
Skor & 91 & - & 120 & Kategori & $\begin{array}{c}\text { Baik } \\
\text { Sekali }\end{array}$ \\
\hline
\end{tabular}

\section{KESIMPULAN DAN SARAN}

\section{Kesimpulan}

Berdasarkan penelitian di atas, dapat disimpulkan bahwa pelaksanaan teknik supervisi klinis yang dilaksanakan di MAN Rejotangan berlangsung dengan baik dan sukses. Melalui teknik supervisi klinis, dapat terbukti bahwa kemampuan guru dalam menyusun RPP sebagai persiapan untuk pelaksanaan proses pembelajaran meningkat. Selain itu, teknik supervisi klinis juga terbukti dapat meningkatkan kemampuan 
mengajar guru mata pelajaran Akidah Akhlak di MAN Rejotangan Kabupaten Tulungagung.

\section{Saran}

Berdasarkan uraian tersebut, saran-saran yang diberikan meliputi (1) Bagi guru mata pelajaran Akidah Akhlak dan guru mata pelajaran lainnya bahwa untuk setiap akan melaksanakan proses pembelajaran hendaknya dipersiapkan RPP terlebih dahulu, sehingga kompetensi yang diharapkan dapat tercapai secara maksimal; (2) Bagi kepala sekolah pada umumnya dan kepala madrasah pada khususnya, hendaknya selalu memberikan anjuran kepada guru dalam memulai proses pembelajaran, hendaknya disarankan untuk mempersiapkan RPP terlebih dahulu agar proses pembelajaran berjalan dengan baik sesuai dengan tujuan; dan (3) Bagi pengawas Pendidikan Agama Islam bahwa teknik supervisi klinis ini merupakan alat yang baik untuk meningkatkan kemampuan guru mata pelajaran dalam proses pembelajaran.

\section{DAFTAR RUJUKAN}

Bafadal, I. 2006. Peningkatan Profesionalisme Guru Sekolah Dasar. Jakarta: Bumi Aksara.

Hariwung, A. J. 1989. Supervisi Pendidikan. Jakarta: Pendidikan Tinggi, Lembaga Pendidik Tenaga Kependidikan.
Kammis, S. and Taggart, M. 1988. The Action Research Planner. Geelong: Deakin University Press.

McNiff, J. 1988. Action Research: Principles and Practice. London: Macmillan Education, Ltd.

Miarso, Y. 1985. Teknologi Komunikasi Pendidikan. Jakarta: Rajawali.

Nawawi, H. 1984. Administrasi Pendidikan. Jakarta: Gunung Agung.

Nurtain. 1989. Supervisi Pengajaran (Teori dan Praktek). Jakarta: Direktorat Jenderal Pendidikan Tinggi, Lembaga Pendidik Tenaga Kependidikan.

Permendiknas Nomor 41 Tahun 2007 tentang Standar Proses untuk Satuan Pendidikan Dasar dan Menengah. 2007. Jakarta: Departemen Pendidikan Nasional.

Purwanto, M. N. 1987. Administrasi dan Supervisi Pendidikan. Bandung: Remadja Karya.

Sahertian, P. A. 2000. Konsep Dasar \& Teknik Supervisi Pendidikan dalam Rangka Pengembangan Sumber Daya Manusia. Jakarta: Rineka Cipta.

Sutisna, O. 1983. Administrasi Pendidikan, Dasar Teoritis untuk Praktek Profesional. Bandung: Angkasa. 